\title{
Soil Amendment with Biochar, Hydrochar and Compost Mitigates the Accumulation of Emerging Pollutants in Rocket Salad Plants
}

\author{
Marco Parlavecchia (D) C Claudia Carnimeo • \\ Elisabetta Loffredo
}

Received: 17 August 2020 / Accepted: 26 October 2020 / Published online: 11 November 2020

(C) The Author(s) 2020

\begin{abstract}
The uptake of organic pollutants by agricultural plants and their accumulation in edible parts cause serious health problems to animals and humans. In this study, we used carbon-rich materials, such as biochar (BC), hydrochar (HC), and green compost (GC), to reduce the absorption and accumulation of three pesticides, imidacloprid (IMI), boscalid (BOS), and metribuzin (MET) and two endocrine disruptors, 4tert-octylphenol (OP) and bisphenol A (BPA), in rocket salad plants (Eruca vesicaria L.). After an experimental period of 35 days, compared to unamended soil, the addition of $\mathrm{BC}, \mathrm{HC}$, and $\mathrm{GC}$ significantly reduced chemical phytotoxicity, increasing the elongation of the aerial plant parts by 26,25 , and $39 \%$, respectively, whereas GC increased the fresh biomass by $21 \%$. The assessment of residual chemicals in both soil and plant tissues indicated that any amendment was very effective in enhancing the retention of all compounds in soil, thus reducing their uptake by plants. Averagely for the five compounds, the reduction of plant absorption followed the trend $\mathrm{BC}>\mathrm{HC}>\mathrm{GC}$. In particular, the presence of $\mathrm{BC}$ decreased the chemical residues in the plants from a minimum of $71 \%$ (IMI) to a maximum of $91 \%$ (OP). The overall results obtained encourage the incorporation in soil of C-rich materials, especially $\mathrm{BC}$, to protect leafy food plants from the absorption and toxicity of
\end{abstract}

M. Parlavecchia $(\bowtie) \cdot$ C. Carnimeo $\cdot$ E. Loffredo

Dipartimento di Scienze del Suolo, della Pianta e degli Alimenti, Università degli Studi di Bari Aldo Moro, Via Amendola 165/A, 70126 Bari, Italy

e-mail: marco.parlavecchia@uniba.it organic pollutants of a wide range of hydrophobicity, with relevant benefits for consumers.

Keywords Contaminant residue $\cdot$ Pesticide $\cdot$ Endocrine disruptor $\cdot$ Plant uptake $\cdot$ Soil amendment

\section{Introduction}

In the last decades, plant protection products (PPPs) have been one of the major groups of emerging organic pollutants released in the environment causing serious risks to human and animal health (Pavlis et al. 2010). In several cases, PPPs have been excessively adopted in agriculture to control crop diseases and increase food production. Approximately, 400,000 tons of PPPs/year are sold in the European Union (European Commission 2018) and about 3 million tons of pesticides are used annually worldwide (Silva et al. 2019). The widespread use of these chemicals determines the presence of unsafe residues in the agro-ecosystems and the consequent entrance in the food chain (Regueiro et al. 2015). From the soil, PPPs, in particular those with low hydrophobicity, can move and leach in surface and underground water bodies (Pavlis et al. 2010).

Imidacloprid (IMI) is one of the most widely used neonicotinoid insecticides in the world and is currently suspected to cause massive damage to bees and users (Crossthwaite et al. 2017). The use on crops of neonicotinoids, such as IMI, is critical because their residues can seriously compromise the health of consumers, even though the extent of the effects on human 
health has not been completely defined (Anderson et al. 2015; Lu et al. 2018). Boscalid (BOS) is a broadspectrum fungicide used particularly against pathogens in specialized high-end crops, such as fruit and horticultural plants (Chen and Zhang 2010). Metribuzin (MET) is a triazinone herbicide used extensively in both preand post-emergence to control broadleaf weeds and annual grasses present in various crops (Mehdizadeh et al. 2019). Because of the high-water solubility, MET has been included into the group of pesticides that have the greatest potential for leaching into groundwater (USEPA 2003). Recently, the European Commission has included IMI, BOS, and MET in the list of suspected endocrine-disrupting chemicals (EDCs) (EU 2016).

Due to the current agricultural practices that make increasing use of waste biomasses and wastewaters not thoroughly decontaminated, in a large number of cases, soil undergoes multiple contamination, being PPPs often co-present with other classes of contaminants, such as EDCs. These compounds include both natural and synthetic organic molecules that influence or inhibit, even at low concentrations, the natural functions of the endocrine system of animals and humans. The occurrence of EDCs in the environment has become more and more widespread due to the increasing anthropic, agroindustrial, and urban activity (Kudłak and Namieśnik 2008). EDCs have often been detected in soil and surface and ground water as a consequence of the discharge of effluents from sewage sludge treatment plants (Ying et al. 2003).

The 4-tert-octylphenol (OP), a xenoestrogen, originates by the microbial breakdown of octylphenol polyethoxylates (OPEOs) which are surfactants used in the formulation of different kind of products, such as paints, detergents, and pesticides (Olaniyan et al. 2018). It is largely present in effluents of sewage treatment plants and can persist in the environment for a long time because of the recalcitrance (Olaniyan et al. 2018). Another well-known EDC is bisphenol A (BPA) that possesses both estrogenic and antiandrogenic activity (Geens et al. 2012). This molecule is widely used for the production of polycarbonate and epoxy resins, flame retardants, and many types of food and drink packaging, such as food cans, bottle caps, and water supply systems (Geens et al. 2012).

While the number and amount of pollutants distributed in soil has grown rapidly in the last years because of intensive agriculture, the progressive decrease of soil organic matter (SOM), and the consequent soil degradation, has become one of the most relevant problems around the world. Plant growth needs healthy soil to guarantee the global and safe food production (Koch et al. 2013). Furthermore, the rapid increase of world population and, consequently, anthropic activities have generated huge quantity of wastes. The recycling and recovery of agricultural and forestry wastes are considered the most sustainable option, especially when they are used to improve the SOM level (Campos et al. 2020). Specialists have developed an ever-increasing number of $\mathrm{C}$-rich materials deriving from the recycling of waste biomasses, including biochar (BC), hydrochar (HC), and compost.

$\mathrm{BC}$ is a C-rich by-product obtained through the pyrolysis of biomass and can be useful to improve soil quality and mitigate climate changes (Lehmann and Joseph 2015). Benefits of the application of BC to soil include the retention of water, plant nutrients, and xenobiotic compounds, such as pesticides and other pollutants (Lehmann and Joseph 2015; Loffredo and Taskin 2017; Parlavecchia et al. 2019). HC is a carbonaceous material produced from the hydrothermal carbonization of wet biomass, at temperature ranging from 180 to $250^{\circ} \mathrm{C}$, under high pressure. Physical and chemical properties of $\mathrm{HC}$ make it suitable for remediation purposes in contaminated environments (Taskin et al. 2019). Compost is a more traditional soil amendment with a high content of organic carbon. Its success at reducing the mobility of different types of contaminants has been largely documented in the literature (Loffredo et al. 2020; Marín-Benito et al. 2018).

When incorporated in soil, compost and, especially, chars are able to immobilize organic xenobiotics, modulating the amount of these molecules in solution and altering their movement and leaching (Gámiz et al. 2016; Loffredo et al. 2020). BC demonstrates high efficiency to retain compounds like IMI (Jin et al. 2016), BOS (Mukherjee et al. 2016), MET (Loffredo et al. 2019), OP (Loffredo and Taskin 2017), and BPA (Hurtado et al. 2017). Although $\mathrm{HC}$ is generally less effective than $\mathrm{BC}$ in immobilizing organic pollutants, due to its lower specific surface and lower $\mathrm{C}$ content, the presence of oxygenated functional groups and the mesoporous structure resulting from the process make $\mathrm{HC}$ an efficient sorbent of pollutants (Loffredo et al. 2019; Yu et al. 2020).

These amendments' behavior is essentially due to the numerous sorption sites present on the organic components where pollutants can be linked with bonds of 
different types and strengths. For instance, MET sorption onto $\mathrm{BC}$ occurs mainly through $\mathrm{H}$ bonds and Coulombic forces and, to a lesser extent, through van der Waals, dipole-dipole, and $\pi-\pi$ interactions (Essandoh et al. 2017). The carbonized phase of BC can adsorb OP through chemical interactions involving covalent and $\mathrm{H}$ bonds (Loffredo and Taskin 2017). Moreover, the humic fraction of compost presents numerous hydrophobic and hydrophilic sites and chemically reactive functional groups (carboxylic and phenolic $\mathrm{OH}$, alcoholic $\mathrm{OH}$, quinonoid and ketonic $\mathrm{C}=\mathrm{O}$, amine groups, and so on) that are responsible for both weak and strong binding with several xenobiotics, including various phenolic EDCs (Loffredo and Senesi 2006).

On the basis of all that, we hypothesized that the use of soil amendments could hinder the uptake of organic pollutants by edible plants. Therefore, we evaluated how the addition of $\mathrm{BC}, \mathrm{HC}$, or a green compost to a loam soil could influence the uptake of IMI, BOS, MET, $\mathrm{OP}$, and BPA by rocket salad (Eruca vesicaria L.) plants.

\section{Materials and Methods}

\subsection{Chemicals, Soil, Amendments, and Plant}

Imidacloprid (IMI), ((2E)-1-[(6-chloropyridin-3yl)methyl]- $N$-nitroimidazolidin-2-imine) at a purity of $99.0 \%$, boscalid (BOS) (2-chloro- $N$-(4'-chlorobiphenyl2-yl)-nicotinamide) at $99.0 \%$ purity, metribuzin (MET) (4-amino-6-tert-butyl-3-(methylsulfanyl)-1,2,4-triazin$5(4 \mathrm{H})$-on) at $\geq 98.0 \%$ purity, 4-tert-octylphenol (OP) at $99.5 \%$ purity, and bisphenol A (BPA) (2,2-Bis(4hydroxyphenyl)propane) at $99.0 \%$ purity were purchased from Sigma-Aldrich S.r.l., Milano, Italy. Some chemical properties of the compounds are reported in Table 1. All other chemicals of extra-pure grade were obtained from commercial sources and used without further purification.

The loamy soil was collected from an experimental station located at Valenzano, Italy. The soil was air dried, and the skeletal fraction was removed by sieving the soil with a $2-\mathrm{mm}$ sieve. Some soil characteristics were determined according to conventional methods. Moisture was measured after heating the soil at $105^{\circ} \mathrm{C}$ overnight. The $\mathrm{pH}$ was measured suspending the soil in distilled water ( $\left.\mathrm{soil} / \mathrm{H}_{2} \mathrm{O}, 1: 2.5, w / v\right)$. Electrical conductivity (EC) was measured by a conductivity meter $\left(\mathrm{soil} / \mathrm{H}_{2} \mathrm{O}, 1: 2, w / v\right)$. Soil organic matter $(\mathrm{SOM})$ was determined by the mass loss on ignition method, heating $10 \mathrm{~g}$ of soil (dried, $<2 \mathrm{~mm}$ ) in a muffle furnace at a temperature of $360{ }^{\circ} \mathrm{C}$ for $2 \mathrm{~h}$ (Zhang and Wang 2014). Moisture, $\mathrm{pH}, \mathrm{EC}$, and SOM of the soil were, respectively, 5.0\% 7.8, $0.23 \mathrm{dS} \mathrm{m}^{-1}$, and $51.3 \mathrm{~g} \mathrm{~kg}^{-1}$.

The BC sample was purchased from Blucomb S.r.l., Udine, Italy. It was obtained from grapevine pruning residues through a process of micro-gasification at maximum temperature of $550{ }^{\circ} \mathrm{C}$ and a residence time of $3 \mathrm{~h}$. Some properties of BC were $4.5 \%$ moisture, $\mathrm{pH}$ value of 9.9, EC value of $2.23 \mathrm{dS} \mathrm{m}^{-1}, 9.9 \%$ ash, and total $\mathrm{C}$ content of $755 \mathrm{~g} \mathrm{~kg}^{-1}$ (Taskin et al. 2019).

The HC sample, whose feedstock was urban pruning residues, was provided by Ingelia Italia S.r.l., Lucca, Italy. It was produced through hydrothermal carbonization process operating between 180 and $210{ }^{\circ} \mathrm{C}$, pressure ranging between 10 and 20 bars, and a residence time of $8 \mathrm{~h}$. A multianalytical characterization of the HC sample is reported in Taskin et al. (2019). Some properties were $7 \%$ moisture, $\mathrm{pH}$ value of $6.6, \mathrm{EC}$ value of $1.03 \mathrm{dS} \mathrm{m}^{-1}, 12.5 \% \mathrm{ash}$, and total $\mathrm{C}$ content of $615 \mathrm{~g} \mathrm{~kg}^{-1}$ (Taskin et al. 2019).

The green compost (GC) sample was produced by Tecnogarden Service S.r.l., Vimercate, Italy, and provided by the Italian Composting and Biogas Association (CIC). It was obtained from the composting of wastes from public and private greenery and residues of crops and wood processing. GC properties were provided by the producer and were $24 \%$ moisture, $\mathrm{pH}$ value of 7.8 , EC value of $1.23 \mathrm{dS} \mathrm{m}^{-1}$, and organic $\mathrm{C}$ content of $270 \mathrm{~g} \mathrm{~kg}^{-1}$.

Rocket salad (Eruca vesicaria L.) seeds were purchased from Royal Seeds S.r.l., Mirandola, Italy.

\subsection{Experimental Conditions}

The experiments were conducted in plexiglass pots (7$\mathrm{cm}$ diameter) filled to a height of $10 \mathrm{~cm}$ with $380 \mathrm{~g}$ of air-dried soil only or the same weight of mixtures of soil and $\mathrm{BC}, \mathrm{HC}$, and $\mathrm{GC}(2.5 \% w / w)$, individually. The base of the pot was closed with wire mesh and glass wool.

All pots were initially watered to $60 \%$ of the field capacity. After about $2 \mathrm{~h}$, a mixture of IMI, BOS, MET, $\mathrm{OP}$, and BPA was incorporated in the upper soil layer $(\sim 5 \mathrm{~cm})$, obtaining in the whole soil a concentration of $1 \mu \mathrm{g} \mathrm{g}^{-1}$ of each compound. After $2 \mathrm{~h}, 8$ rocket salad seeds were sowed in each pot of half of the series of pots 
Table 1 Some properties of the compounds. Data from PubChem (2020)

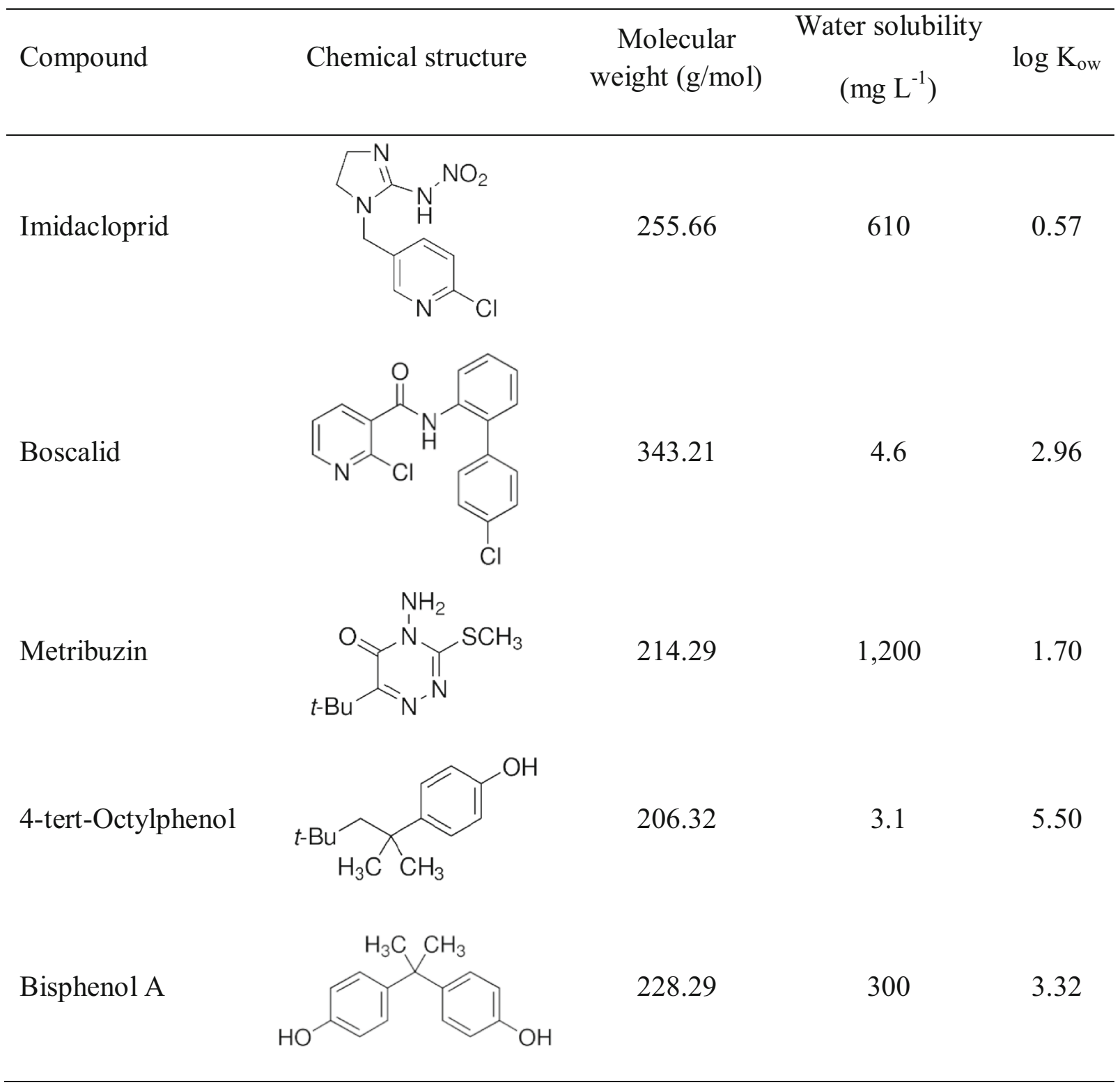

prepared, whereas the other half number of pots was left without plants (bare soil). The treatments obtained were soil, soil + BC, soil + HC, soil + GC, soil + plants, soil + $\mathrm{BC}+$ plants, soil $+\mathrm{HC}+$ plants, soil $+\mathrm{GC}+$ plants, and uncontaminated soil + plants (UC-soil). Then, a volume of $10 \mathrm{~mL}$ of distilled $\mathrm{H}_{2} \mathrm{O}$ was added to each pot (with and without seeds). During the duration of the experiments (35 days), each column was added with $10 \mathrm{~mL}$ of water day ${ }^{-1}$ (total volume of $350 \mathrm{~mL}$ ). The experiments were conducted in a climatic chamber (F.lli Della Marca
S.r.l., Roma, Italy) with 10 -h photoperiod, relative humidity of $60 \%$, a temperature of $21 \pm 1{ }^{\circ} \mathrm{C}$ during the light hours and $16 \pm 1{ }^{\circ} \mathrm{C}$ during the dark hours. Pots with plants of 20-day growth are showed in Fig. 1.

\subsection{Biometric Measurements}

At the end of experiments, rocket salad plants were collected, roots were rinsed with distilled water, and 
root and shoot lengths and fresh and dry weights (at $70{ }^{\circ} \mathrm{C}$ for $16 \mathrm{~h}$ ) of plants were measured.

2.4 Extraction of the Compounds from Soil and Plant Tissues

At the end of experiments, the pots were dismantled and the soil was homogenized by mixing thoroughly. An aliquot of $20 \mathrm{~g}$ of soil was taken from each sample, added with $50 \mathrm{~mL}$ of methanol, and kept under mechanical shaking overnight $(16 \mathrm{~h})$. After filtration of the suspension, an aliquot of $20 \mathrm{~mL}$ of the extract was centrifuged at $10,000 \times g$ for $10 \mathrm{~min}$. Then, the supernatant solution was analyzed by high performance liquid chromatography (HPLC) (section 2.5).

Previous experiments evaluated the recoveries from the soil of the compounds at concentrations of $1 \mu \mathrm{g} \mathrm{g}^{-1}$ with the above procedure. The percentages of recovery of IMI, BOS, MET, OP, and BPA were, respectively, $96.00 \pm 3.42,95.96 \pm 1.61,92.20 \pm 1.61,91.08 \pm 2.08$, and $92.40 \pm 0.71$.

Extraction of the compounds from the plants was done according to the procedure described by Ferrara et al. (2006). Briefly, $0.3 \mathrm{~g}$ of dried plant mass from each pot was added with $10 \mathrm{~mL}$ of pure methanol and kept under mechanical shaking for $4 \mathrm{~h}$. The suspension was then centrifuged at $10,000 \times g$ for $10 \mathrm{~min}$ and a volume of $5 \mathrm{~mL}$ of the supernatant solution was evaporated to dryness at a temperature of $40{ }^{\circ} \mathrm{C}$ using a rotatory evaporator. The solid residue was dissolved in a volume of $2 \mathrm{~mL}$ of acetonitrile/water mixture $(70: 30, v / v)$, filtered through $0.45 \mu \mathrm{m}$ Millipore ${ }^{\mathrm{TM}}$ cellulose acetate filters and analyzed by HPLC (section 2.5).

\subsection{Analytical Measurements}

Residual compounds were measured using a HPLC apparatus equipped with a Spectra System ${ }^{\mathrm{TM}}$ pump (Thermo Electron Corporation, San Jose, CA, USA) and a Rheodyne ${ }^{\circledR} 7125$ injector fitted with a $20-\mu \mathrm{L}$ loop. The chromatographic column was a SupelcosiliM LC-18 $(250 \mathrm{~mm} \times 4.6 \mathrm{~mm} \times 5 \mu \mathrm{m})$. The mobile phase was a mixture of water (A) and acetonitrile (B). The elution gradient was the following: 0-1 $\min 60 \% \mathrm{~A}, 1-$ 4 min from 60 to $50 \%$ A, 4-8 min from 50 to $30 \%$ A, 8 12 min from 30 to $10 \%$ A, 12-14 min $10 \%$ A. Using a flow rate of $0.8 \mathrm{~mL} \mathrm{~min}^{-1}$, the retention times of IMI, MET, BPA, BOS, and OP were, respectively, about 3.4, 4.0, 6.2, 9.2 and $13.6 \mathrm{~min}$. The compounds IMI, BOS and MET were detected using a Spectra System UV6000LPTM diode array detector (Thermo Electron Corporation, San Josè, CA, USA) at wavelengths of $269 \mathrm{~nm}, 207 \mathrm{~nm}$, and $294 \mathrm{~nm}$, respectively. OP and BPA were detected using a fluorescence detector Spectra SystemFL3000 (Thermo Electron Corporation, San Josè, CA, USA) operating at wavelengths of 230-nm excitation and 310-nm emission.

\subsection{Statistical Analysis}

All the experiments performed in this work were triplicated. Biometric data of plants were statistically analyzed by one-way analysis of variance (ANOVA), and the means of the treatments were compared to the control by the least significant difference (LSD) test at $0.05 P, 0.01 P$, and $0.001 P$ levels. Data of the residual compounds extracted from the soil were analyzed by two-way ANOVA, and the means were separated at $0.05 P$ using the Duncan's multiple range test for the main factors and the LSD test for the interaction. Data of residual compounds extracted from the plants were analyzed by one-way ANOVA and the means separated by the Duncan's multiple range test at $0.05 \mathrm{P}$ level.

\section{Results and Discussions}

\subsection{Plant Response to Soil Contamination}

Rocket salad plants grown for 35 days in the multicontaminated soil not amended or amended with $\mathrm{BC}, \mathrm{HC}$, or GC did not show visual alterations, except a delayed growth, compared to plants grown in UC-soil, as shown in Fig. 1. Biometric data of plants grown in the contaminated soil clearly indicated a lower root and shoot elongation and less production of fresh and dry biomass, compared to plants grown in UC-soil, denoting evident toxicity of the chemicals on this plant (Fig. 2).

In previous studies, individual applications of these compounds exerted differentiated responses by various plant species. Stevens et al. (2007) reported that IMI did not cause adverse effects on plant growth if applied to pregerminated rice seeds shortly before sowing, and that continuous exposure of seedlings to IMI could even stimulate rice growth. Ruela et al. (2019) observed a general positive effect of BOS on root and shoot length and fresh weight of coffee seedlings. Sondhia (2005) observed that MET concentrations between 0 and 
Fig. 1 Pots with rocket salad plants

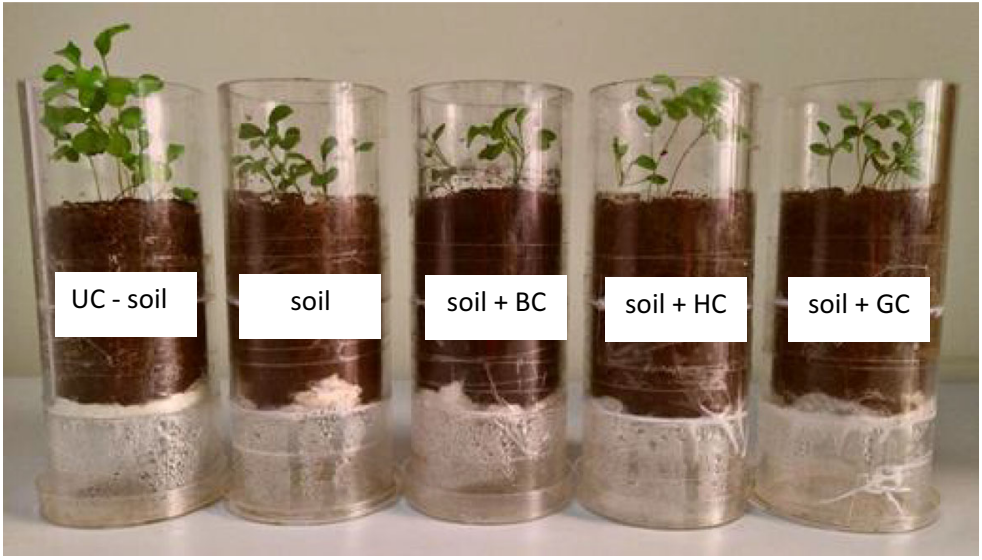

$5.0 \mu \mathrm{g} \mathrm{g}^{-1}$ significantly reduced cucumber and sorghum root and shoot growth. Patama et al. (2019) studying the effects of the EDC OP on the flowering plant Gypsophila elegans (annual baby's breath), found a significant inhibition on both root and shoot elongation. Doses of 4.6 and $46 \mu \mathrm{g} \mathrm{g}^{-1}$ of BPA altered the root morphology and reduced fresh weight of 16-day seedlings of ryegrass and radish (Loffredo et al. 2010).

The toxicity of these compounds on rocket salad plants was significantly reduced by the incorporation of the amendments in the soil. In fact, compared to untreated soil, the addition of $\mathrm{BC}, \mathrm{HC}$, and $\mathrm{GC}$
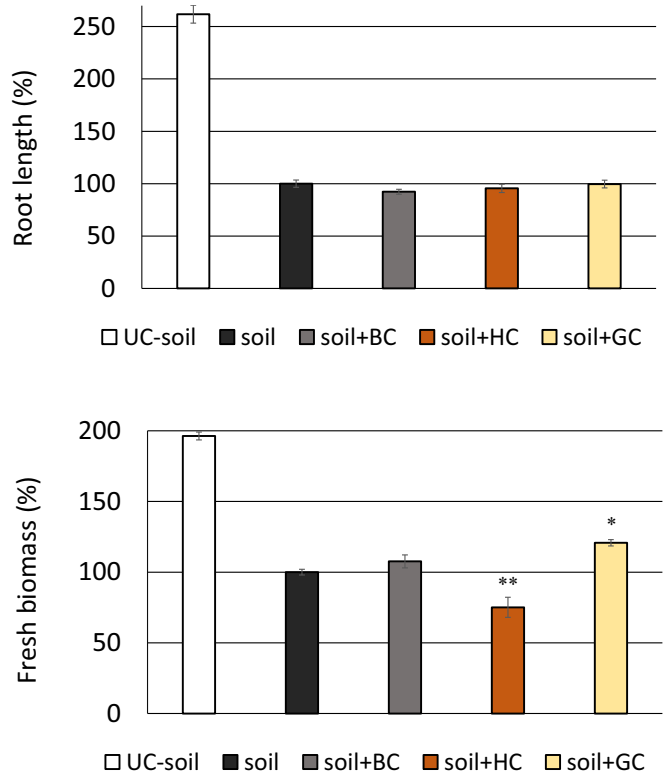

Fig. 2 Biometric data of rocket salad plants grown in uncontaminated soil (UC-soil) and contaminated soil only (soil, 100\%) or amended with BC (soil + BC), HC (soil + HC), and GC (soil + GC). The vertical line on each bar indicates the standard error $(n=$ increased the shoot length by $26.3,25.0$, and $39.1 \%$, respectively. Moreover, GC increased the fresh weight of plants by $20.8 \%$, whereas a reduction was produced by soil $+\mathrm{HC}$ (Fig. 2). These results clearly indicate the occurrence of plant-protective effects by these materials. The general positive effect on plant growth can be, at least partially, attributed to the capability of the amendments to retain the molecules, as extensively reported in the literature (Ferreira Mendes et al. 2019; Hurtado et al. 2017; Loffredo and Taskin 2017). As regards the contrasting effects of GC and $\mathrm{HC}$ on the biomass production of this plant, we can assume that some components
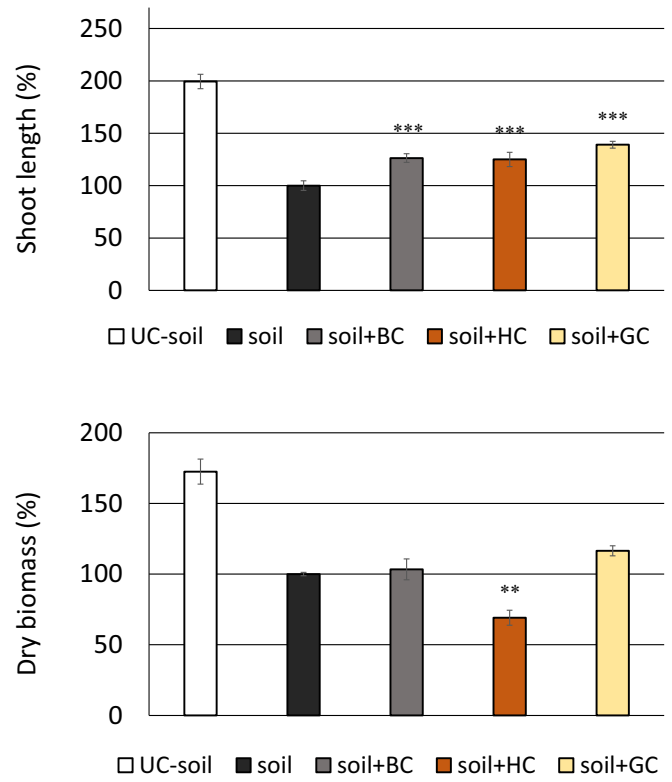

3). Data were statistically treated with one-way ANOVA, and the means of the treatments were compared to the soil only by the LSD test. $* P \leq 0.05 ; * * P \leq 0.01 ; * * * P \leq 0.001$ 
of $\mathrm{HC}$, such as aromatic hydrocarbons, might have caused some phytotoxic effects (Taskin et al. 2019).

\subsection{Residual Contaminant in the Soil}

During the 35-day plant growth, the five molecules underwent a series of different processes in the soil, such as uptake by plants, adsorption on the solid fraction, and degradation. Considering the residual compounds found in bare soil and those found in planted soil, the important role of plants was evident in decreasing soil contamination from the five molecules. Averagely for the treatments, residue reduction was highly significant $(P \leq 0.01)$ for each compound (Table 2$)$. Moreover, when the amounts of compounds removed by plants (calculated as the difference between the residue in bare soil and planted soil) were related to the corresponding $\log K_{\mathrm{ow}}$, a significant $(P \leq 0.05)$ inverse correlation was found, indicating the importance of the hydrophobic character of the molecule in the plant uptake process. This relationship has already been evidenced by researchers (Jayampathi et al. 2019; Sharma et al. 2020). However, it should be evidenced that plant removal cannot be ascribed only to absorption, because we assume that plant exudates might have had a role in enhancing contaminant degradation in the rhizosphere. In this study, it was not possible to discriminate the two processes.

Among the five compounds, IMI was the most removed by plants both in the unamended soil and, on average, in all treatments (Table 2). That can be reasonably attributed to the very low hydrophobicity of this molecule that may easily move in the soil solution, enter the rhizosphere and be absorbed by the root system with the water flow. In soil + plants treatments, compared to the unamended soil, the addition of $\mathrm{BC}$ and $\mathrm{HC}$ significantly $(P \leq 0.01)$ increased the percentage of IMI found in the soil, denoting a noticeable retention of this molecule in amended soil that contrasted plant absorption (Table 2). Liu et al. (2006) reported that IMI sorption in soil increased with the increasing of SOM content. Studying the effects of $\mathrm{BC}$ addition on the adsorption of a mixture of pesticides in soil, including IMI, Jin et al. (2016), demonstrated the direct relationship between the dose of the amendment and the quantity of mixture adsorbed. The authors attributed that to the increased content of total $\mathrm{C}$ in the soil. In our study, GC addition did not significantly increase residual IMI in planted soil, suggesting either a low capacity of GC to retain
Table 2 Effects of treatment, plants, and their interaction on the percentage of compound found after 35 days in the soil, compared to the initial amount added $(100 \%)$

\begin{tabular}{|c|c|c|c|}
\hline Treatment & Bare soil & Soil + plants & Average \\
\hline \multicolumn{4}{|c|}{ IMI; $0.05 P=5.9^{\mathrm{a}}$} \\
\hline Soil & 76.9 & 43.2 & $60.1 \mathrm{~b}$ \\
\hline Soil + BC & 76.8 & 60.0 & $68.4 \mathrm{a}$ \\
\hline Soil + HC & 77.4 & 61.6 & $69.5 \mathrm{a}$ \\
\hline Soil + GC & 71.0 & 48.3 & $59.7 \mathrm{~b}$ \\
\hline Average & $75.5 \mathrm{a}$ & $53.3 \mathrm{~b}$ & \\
\hline \multicolumn{4}{|c|}{ BOS; $0.05 P=4.5$} \\
\hline Soil & 77.7 & 57.8 & $67.8 \mathrm{a}$ \\
\hline Soil + BC & 71.5 & 63.1 & $67.3 \mathrm{a}$ \\
\hline Soil + HC & 73.5 & 66.5 & $70.0 \mathrm{a}$ \\
\hline Soil + GC & 68.1 & 53.6 & $60.9 \mathrm{~b}$ \\
\hline Average & $72.7 \mathrm{a}$ & $60.3 \mathrm{~b}$ & \\
\hline \multicolumn{4}{|c|}{ MET; $0.05 P=8.9$} \\
\hline Soil & 77.5 & 46.3 & $61.9 \mathrm{~b}$ \\
\hline Soil + BC & 75.0 & 62.9 & $69.0 \mathrm{a}$ \\
\hline Soil + HC & 71.1 & 58.6 & $64.9 \mathrm{ab}$ \\
\hline Soil + GC & 69.5 & 47.7 & $58.6 \mathrm{~b}$ \\
\hline Average & $73.3 \mathrm{a}$ & $53.9 \mathrm{~b}$ & \\
\hline \multicolumn{4}{|c|}{$\mathrm{OP} ; 0.05 P=6.2$} \\
\hline Soil & 78.1 & 65.7 & $71.9 \mathrm{bc}$ \\
\hline Soil + BC & 81.1 & 79.9 & $80.5 \mathrm{a}$ \\
\hline Soil + HC & 76.3 & 73.0 & $74.7 \mathrm{~b}$ \\
\hline Soil + GC & 71.8 & 62.6 & $67.2 \mathrm{c}$ \\
\hline Average & $76.8 \mathrm{a}$ & $70.3 \mathrm{~b}$ & \\
\hline \multicolumn{4}{|c|}{$\mathrm{BPA} ; 0.05 P=5.3$} \\
\hline Soil & 77.2 & 65.2 & $71.2 \mathrm{~b}$ \\
\hline Soil + BC & 76.7 & 74.0 & $75.4 \mathrm{a}$ \\
\hline Soil + HC & 74.7 & 73.3 & $74.0 \mathrm{ab}$ \\
\hline Soil + GC & 66.5 & 64.9 & $65.7 \mathrm{c}$ \\
\hline Average & $73.8 \mathrm{a}$ & $69.4 \mathrm{~b}$ & \\
\hline
\end{tabular}

Note: Data were statistically treated with two-way ANOVA, and significant differences between means are shown by different letters according to the Duncan's multiple range test at $P \leq 0.05$

${ }^{\text {a }}$ LSD for the interaction treatment $\times$ plants at $P \leq 0.05(n=3)$

IMI or an increased degradation promoted by GC. Recently, Kumari et al. (2018) proved the moderate capability of a mixture of compost and peat to adsorb IMI.

Residual BOS in bare soil was significantly $(P \leq$ 0.01 ) reduced by the addition of $\mathrm{BC}$ and $\mathrm{GC}$, indicating a role of these materials in the degradation process of this molecule in soil (Table 2). These results are in 
agreement with those previously obtained by other researchers (Mukherjee et al. 2014, 2016). On the other hand, in planted soil, $\mathrm{BC}$ and $\mathrm{HC}$ reduced the amount of BOS removed by plants, possibly because of the marked retention of BOS by the two materials that counteracted plant uptake (Table 2). Mukherjee et al. (2016) showed that the addition to the soil of a biomixture containing $\mathrm{BC}$ increased the sorption of BOS.

The presence of plants reduced residual MET in all treatments of soil. On the other hand, the addition of the amendments did not affect significantly residual MET in bare soil, indicating that these materials did not influenced the degradation of this molecule in soil (Table 2). This is in contrast with what was reported by Mehdizadeh et al. (2019), who found that a green compost could promote the decay of this herbicide in soil, mostly thanks to the stimulation of degrading microbes. Benoit et al. (2007) studied the pathways of MET disappearance in soil and concluded that biodegradation was the foremost process. The presence of $\mathrm{BC}$ and $\mathrm{HC}$ favored the permanence of MET in planted soil, indicating their role in the retention of this compound in soil and the negative effects on plant removal (Table 2). The relevant sorption potential of BC towards MET has recently been demonstrated (Loffredo et al. 2019).

In bare soil, only the addition of GC significantly reduced the residual OP, indicating that this amendment promoted the degradation of OP, possibly stimulating microbial activity. Loffredo et al. (2016) demonstrated the noticeable capacity of ligninolytic fungi to degrade OP. The presence of plants significantly changed the quantity of OP residues in soil, compared to bare soil (Table 2). In the treatments with plants, maximum OP residues were found in soil $+\mathrm{BC}$ and soil $+\mathrm{HC}$. This finding might be ascribed to both the retention of OP by the materials, that competed with root uptake, and the lesser availability of root exudates. In fact, less polar components of root exudates, such as phenolic acids, might have been adsorbed by the materials and therefore be less available for soil-resident microorganisms. The strong sorption capability of $\mathrm{BC}$ towards $\mathrm{OP}$ was previously demonstrated by Loffredo and Taskin (2017).

The behavior of BPA in both bare and planted soil was very similar to that of OP. Therefore, all the considerations done for OP can be extended also to this molecule. Results obtained for BPA were in agreement with the findings of $\mathrm{Xu}$ et al. (2015) who found that BC reduced BPA mobility in soil but did not affect its degradation. As by Shi et al. (2019), the retention and transport in soil of BPA is strictly related to the level of SOM. Hurtado et al. (2017) demonstrated that the addition of $\mathrm{BC}$ to soil increased the retention capability of BPA, and that, enhancing BC dose in soil from 2.5 to $5 \%$, the retention of this compound increased by $50 \%$.

\subsection{Accumulation of the Compounds in the Plant}

Based on the results of residual compounds in bare and planted soil, it was expected that the plants did not only absorbed the contaminants but also accumulated them in their tissues. The amounts of residual compounds extracted from the plants of the various treatments after 35day growth are shown in Table 3 . In all treatments with the amendments and for all the molecules examined, the amount of compound accumulated in the plants was significantly $(P \leq 0.05)$ lower than that accumulated in plants grown in unamended soil (Table 3 ). These results evidenced the important role of the amendments in contrasting the uptake and accumulation of contaminants in plant tissues.

When the soil was added with $\mathrm{BC}, \mathrm{HC}$, and GC, individually, residual IMI present in rocket salad was, respectively, $28.7,53.0$, and $60.1 \%$ of IMI accumulated in plants grown in unamended soil. These results clearly indicated that the relevant retention of the molecules by the three amendments greatly attenuated the uptake and accumulation of IMI by the plants, in the order BC $>\mathrm{HC}$ $>$ GC. Sur and Stork (2003) reported that the uptake of IMI by plants, after seed dressing or direct application to soil, depended on the plant species, being lower in rice (4.5\%) and cotton (4.9\%) and higher in corn (20.0\%). In our study, the amount of IMI removed by rocket salad in the unamended soil was more than $30 \%$ (Table 2), indicating a considerable susceptibility of this plant to absorb this contaminant from the soil. Consequently, any treatment able to attenuate the plant uptake of IMI is very important for the security of this leafy plant. The percentage of IMI accumulated in plants, compared to that removed from the soil, was significantly lower for all treatments, compared to unamended soil, in the order soil + BC $=$ soil $+\mathrm{HC}<$ soil + GC $($ Table 4$)$. This finding suggested that these materials, in addition to influencing plant absorption, might also have affected the rate of transformation of IMI by plants. Further studies could elucidate this aspect.

In general, the fungicide BOS was absorbed by plants to a lesser extent than IMI, and its accumulation was 
Table 3 Amounts ( $\mu$ g per g of dry plant mass) of residual compounds extracted from rocket salad plants after 35-day growth

\begin{tabular}{lrrrr}
\hline Compound & \multicolumn{1}{l}{ Soil } & Soil $+\mathrm{BC}$ & \multicolumn{1}{c}{ Soil + HC } & Soil + GC \\
\hline IMI & $178.39 \pm 0.86^{\mathrm{a}} \mathrm{a}$ & $51.17 \pm 1.32 \mathrm{~d}$ & $94.56 \pm 2.71 \mathrm{c}$ & $107.24 \pm 4.01 \mathrm{~b}$ \\
BOS & $88.63 \pm 1.89 \mathrm{a}$ & $15.69 \pm 1.89 \mathrm{c}$ & $45.23 \pm 2.00 \mathrm{~b}$ & $50.86 \pm 0.91 \mathrm{~b}$ \\
MET & $142.55 \pm 4.60 \mathrm{a}$ & $35.98 \pm 2.79 \mathrm{c}$ & $73.73 \pm 2.00 \mathrm{~b}$ & $81.87 \pm 1.70 \mathrm{~b}$ \\
OP & $53.08 \pm 1.45 \mathrm{a}$ & $5.01 \pm 0.23 \mathrm{c}$ & $24.85 \pm 1.79 \mathrm{~b}$ & $26.87 \pm 0.48 \mathrm{~b}$ \\
BPA & $69.73 \pm 2.09 \mathrm{a}$ & $11.46 \pm 0.87 \mathrm{c}$ & $32.93 \pm 1.85 \mathrm{~b}$ & $39.28 \pm 1.64 \mathrm{~b}$
\end{tabular}

Note: Data were statistically analyzed by one-way ANOVA, and significant differences between means of each row are shown by different letters according to the Duncan's multiple range test at $P \leq 0.05$

${ }^{\text {a }}$ Standard error of the mean $(n=3)$

significantly reduced by all amendments, especially BC (Table 3$)$. No significant $(P \leq 0.05)$ difference was observed in soil $+\mathrm{HC}$ and soil $+\mathrm{GC}$ treatments. The individual presence of $\mathrm{BC}, \mathrm{HC}$, and $\mathrm{GC}$ reduced the presence of BOS in the plants by $82.3,51.22$, and $42.6 \%$, respectively, compared to unamended soil. Jeon et al. (2014) reported very low uptake rates of BOS in Korean cabbages. Compared to soil only, in all treatments, the percentage of residual BOS in plants, with respect to that removed from the soil, was significantly lower (Table 4). Also for this molecule, it seemed that the addition of the materials to the soil somehow stimulated the transformation of the compound into the plant tissues.

All soil amendments reduced the amount of MET found in rocket salad tissues. This effect was more pronounced for soil $+\mathrm{BC}$ and less for the other two treatments which did not differ statistically from each other. Compared to untreated soil, residual MET in plants grown in soil amended with $\mathrm{BC}, \mathrm{HC}$, and GC was reduced by $74.8,48.3$, and $42.6 \%$, respectively (Table 3). The percentage of MET accumulated in the plant mass, compared to the quantity removed from soil, was significantly lower when soil was added with the amendments (Table 4). This suggests that the addition of all the materials influenced the metabolization of MET by plants.

The OP was the molecule less abundant in rocket salad in all treatments (Table 3). The hydrophobic character of this compound must have played an important role in reducing its mobility both in soil and in plants. A relevant reduction of residual OP in the plants was observed in soil + BC treatment, and a lesser effect with the other two amendments without any significant difference between them. The amendment of soil with $\mathrm{BC}$, $\mathrm{HC}$, and GC significantly reduced the residual OP in the plants by $90.6,53.2$, and $49.4 \%$, respectively. Similarly to what was observed for the other compounds, plant metabolization of OP seemed to be influenced by the addition of the materials, with the lower percentage of OP accumulated in soil + BC treatment (Table 4). Unfortunately, in literature, there are no data concerning the effects of soil amendment on the accumulation of MET and $\mathrm{OP}$ in plant tissues.

The amount of BPA accumulated in the plants was quite low, compared to pesticides accumulation, especially in the cases of IMI and MET. A very limited amount of residual BPA $\left(11.46 \mu \mathrm{g} \mathrm{g}^{-1}\right)$ was detected in the plants grown in soil $+\mathrm{BC}$ treatment (Table 3). That might depend on the high hydrophobicity of this molecule that made plant uptake more difficult. Anyhow, residual BPA in rocket salad plants was significantly reduced by the addition of any amendment (Table 3). In fact, compared to untreated soil, BPA percentage found in the plants decreased to $85.6,52.8$, and $43.7 \%$ in the presence of BC, HC, and GC, respectively. As already observed for BOS, MET, and $\mathrm{OP}$, the effects produced by the addition of $\mathrm{HC}$ and GC to the soil were very similar and statistically not different (Table 3). It is conceivable that if on the one hand $\mathrm{HC}$ retained the compounds in the soil to a greater extent than GC, on the other hand, GC might have stimulated the degradation activity of microorganisms more than HC. Both of these effects were effective, probably to a similar extent, in reducing the amount of contaminant absorbed and accumulated in the plants. Our results are in agreement with those of Hurtado et al. (2017) who found that BPA absorption by lettuce plants decreased with increasing amounts of $\mathrm{BC}$ added to the soil. Comparing the residual BPA in plant tissues to that removed by the plants from soil, it was evident that the amendments influenced not only the quantity of BPA 
Table 4 Percentage of residual compound in plant mass compared to the quantity that the plants removed from the soil

\begin{tabular}{llrrr}
\hline Compound & Soil & Soil + BC & Soil + HC & Soil + GC \\
\hline IMI & $53.55 \pm 2.76^{\mathrm{a} a}$ & $22.43 \pm 1.37 \mathrm{c}$ & $28.93 \pm 1.31 \mathrm{c}$ & $41.21 \pm 3.59 \mathrm{~b}$ \\
BOS & $35.77 \pm 1.27 \mathrm{a}$ & $7.35 \pm 0.42 \mathrm{~d}$ & $15.01 \pm 0.52 \mathrm{c}$ & $21.66 \pm 0.48 \mathrm{~b}$ \\
MET & $45.99 \pm 5.15 \mathrm{a}$ & $16.96 \pm 0.91 \mathrm{c}$ & $20.93 \pm 1.39 \mathrm{bc}$ & $31.16 \pm 2.29 \mathrm{~b}$ \\
OP & $26.31 \pm 0.37 \mathrm{a}$ & $4.55 \pm 0.93 \mathrm{~d}$ & $10.82 \pm 1.06 \mathrm{c}$ & $14.34 \pm 1.12 \mathrm{~b}$ \\
BPA & $34.03 \pm 0.52 \mathrm{a}$ & $7.87 \pm 1.17 \mathrm{~d}$ & $14.40 \pm 0.16 \mathrm{c}$ & $22.36 \pm 2.42 \mathrm{~b}$
\end{tabular}

Note: Data were statistically analyzed by one-way ANOVA, and significant differences between means of each row are shown by different letters according to the Duncan's multiple range test at $P \leq 0.05$

${ }^{\text {a }}$ Standard error of the mean $(n=3)$

removed but possibly also the rate of metabolization of this compound by plants (Table 4). Unfortunately, no information is present in the literature on this matter.

Finally, when residual compounds accumulated in the plants of the various treatments (data in Table 3) were related to the corresponding $\log K_{\text {ow }}$ of the molecules, significant inverse correlations were obtained for soil $(r=-0.953)$, soil + BC $(r=-0.947)$, soil $+\mathrm{HC}(r=$ $-0.947)$, and soil $+\mathrm{GC}(r=-0.960)$, indicating the crucial role of the contaminant hydrophobicity in the accumulation of residues in the plant.

\section{Conclusions}

Results obtained indicated that the addition to soil of $\mathrm{BC}, \mathrm{HC}$, and GC increased the overall sorption capability of the soil towards all the five compounds considered in this study, with a consequent drastic reduction of the bioavailability of the molecules. Consequently, the amount of the compounds absorbed and accumulated in plant tissues decreased noticeably with soil amendment. Among the three materials tested, $\mathrm{BC}$ demonstrated the best efficacy in contrasting plant uptake of any compound, followed in order by $\mathrm{HC}$ and GC. The fraction of the compound accumulated by plants, with respect to that removed from the soil, seemed to be influenced by the amendment adopted, indicating a role of these materials also in the transformation of the contaminants by the plant. The hydrophobic character of the molecule played a crucial role in the plant uptake and accumulation, with the least polar compound being the least accumulated.

Acknowledgments The authors thank the Italian Composting and Biogas Association (CIC) for providing the green compost.
Funding Open access funding provided by Università degli Studi di Bari Aldo Moro within the CRUI-CARE Agreement. This work was funded by University of Bari Aldo Moro, Italy.

Open Access This article is licensed under a Creative Commons Attribution 4.0 International License, which permits use, sharing, adaptation, distribution and reproduction in any medium or format, as long as you give appropriate credit to the original author(s) and the source, provide a link to the Creative Commons licence, and indicate if changes were made. The images or other third party material in this article are included in the article's Creative Commons licence, unless indicated otherwise in a credit line to the material. If material is not included in the article's Creative Commons licence and your intended use is not permitted by statutory regulation or exceeds the permitted use, you will need to obtain permission directly from the copyright holder. To view a copy of this licence, visit http://creativecommons.org/licenses/by/4.0/.

\section{References}

Anderson, J. C., Dubetz, C., \& Palace, V. P. J. (2015). Neonicotinoids in the Canadian aquatic environment. A literature review on current use products with a focus on fate, exposure, and biological effects. Science of the Total Environment, 505, 409-422. https://doi.org/10.1016/j. scitotenv.2014.09.090.

Benoit, P., Perceval, J., Stenrod, M., Moni, C., Eklo, O. M., Barriuso, E., Sveistrup, T., \& Kvaerner, J. (2007). Availability and biodegradation of metribuzin in alluvial soils as affected by temperature and soil properties. Weed Research, 47, 517-526. https://doi.org/10.1111/j.13653180.2007.00589.x.

Campos, P., Miller, A. Z., Knicker, H., Costa-Pereira, M. F., Merino, A., \& De la Rosa, J. M. (2020). Chemical, physical and morphological properties of biochars produced from agricultural residues: Implications for their use as soil amendment. Waste Management, 105, 256-267. https://doi. org/10.1016/j.wasman.2020.02.013.

Chen, L., \& Zhang, S. (2010). Dissipation and residues of boscalid in strawberries and soils. Bulletin of Environmental Contamination and Toxicology, 84, 301-304. https://doi. org/10.1007/s00128-010-9934-y. 
Crossthwaite, A. J., Bigot, A., Camblin, P., Goodchild, J., Lind, R. J., Slater, R., \& Maienfisch, P. (2017). The invertebrate pharmacology of insecticides acting at nicotinic acetylcholine receptors. Journal of Pesticide Science, 42(3), 67-83. https://doi.org/10.1584/jpestics.D17-019.

Essandoh, M., Wolgemuth, D., Pittman Jr., C. U., Mohan, D., \& Mlsna, T. (2017). Adsorption of metribuzin from aqueous solution using magnetic and nonmagnetic sustainable lowcost biochar adsorbents. Environmental Science and Pollution Research, 24, 4577-4590. https://doi.org/10.1007 /s11356-016-8188-6.

European Commission. Sales of pesticides in the EU. (2018) (https:/ec.europa.eu/eurostat/web/products-eurostat-news//DDN-20181015-1 Accessed 13 August 2020.

European Commission (EU). Defining criteria for identifying endocrine disruptors in the context of the implementation of the plant protection products regulation and biocidal products regulation. (2016) https:// ec.europa. eu/transparency/regdoc/rep/10102/2016/EN/SWD-2016211-F1-EN-MAIN-PART-6.PDF Accessed 13 August 2020.

Ferrara, G., Loffredo, E., \& Senesi, N. (2006). Phytotoxic, clastogenic and bioaccumulation effects of the environmental endocrine disruptor bisphenol $\mathrm{A}$ in various crops grown hydroponically. Planta, 223, 910-916. https://doi. org/10.1007/s00425-005-0147-2.

Ferreira Mendes, K., Nogueira de Sousa, R., Takeshita, V., Gimenes Alonso, F., Justiniano Régo, A. P., \& Tornisielo, V. L. (2019). Cow bone char as a sorbent to increase sorption and decrease mobility of hexazinone, metribuzin, and quinclorac in soil. Geoderma, 343, 40-49. https://doi. org/10.1016/j.geoderma.2019.02.009.

Gámiz, B., Pignatello, J. J., Cox, L., Hermosín, M. C., \& Celis, R. (2016). Environmental fate of the fungicide metalaxyl in soil amended with composted olive-mill waste and its biochar: An enantioselective study. Science of the Total Environment, 54,776-783. https://doi.org/10.1016/j. scitotenv.2015.09.097.

Geens, T., Aerts, D., Berthod, C., Bourguignon, J.-P., Goeyens, L., Lecomte, P., Maghuin-Rogister, G., Pironnet, A.-M., Pussemier, L., Scippo, M.-L., Van Loco, L., \& Covaci, A. (2012). A review of dietary and non-dietary exposure to bisphenol-A. Food and Chemical Toxicology, 50(10), 3725-3740. https://doi.org/10.1016/j.fct.2012.07.059.

Hurtado, C., Cañameras, N., Domínguez, C., Price, G. W., Comas, J., \& Bayona, J. M. (2017). Effect of soil biochar concentration on the mitigation of emerging organic contaminant uptake in lettuce. Journal of Hazardous Materials, 323A, 386393. https://doi.org/10.1016/j.jhazmat.2016.04.046.

Jayampathi, T., Atugoda, T., \& Jayasinghe, C. (2019). Uptake and accumulation of pharmaceuticals and personal care products in leafy vegetables, in pharmaceuticals and personal care products: Waste management and treatment technology. Emerging Contaminants and Micro Pollutants, 87-113. https://doi.org/10.1016/B978-0-12-816189-0.00004-4.

Jeon, S.-o., Hwang, J.-I., Lee, S.-h., \& Kim, J.-E. (2014). Uptake of boscalid and chlorfenapyr residues in soil into Korean cabbage. The Korean Journal of Pesticide Science, 18(4), 314-320. https://doi.org/10.7585/kjps.2014.18.4.314.

Jin, J., Kang, M., Sun, K., Pan, Z., Wu, F., \& Xing, B. (2016). Properties of biochar-amended soils and their sorption of imidacloprid, isoproturon, and atrazine. Science of the Total
Environment, 550, 504-513. https://doi.org/10.1016/j. scitotenv.2016.01.117.

Koch, A., McBratney, A., Adams, M., Field, D., Hill, R., et al. (2013). Soil security: Solving the global soil crisis. Global Policy, 4, 434-441. https://doi.org/10.1111/17585899.12096.

Kudłak, B., \& Namieśnik, J. (2008). Environmental fate of endocrine disrupting compounds - analytical problems and challenges. Critical Reviews in Analytical Chemistry, 38, 242258. https://doi.org/10.1080/10408340802378239.

Kumari, A., Mandal, A., \& Singh, N. (2018). Kinetic and isotherm modeling of azoxystrobin and imidacloprid retention in biomixtures. Journal of Environmental Science and Health, Part B, 54(2), 118-128. https://doi.org/10.1080 /03601234.2018.1507230.

Lehmann, J., \& Joseph, S. (2015). Biochar for environmental management: Science and technology (2nd ed.). London: Earthscan.

Liu, W., Zheng, W., Ma, Y., \& Liu, K. K. (2006). Sorption and degradation of imidacloprid in soil and water. Journal of Environmental Science and Health, Part B, 41, 623-634. https://doi.org/10.1080/03601230600701775.

Loffredo, E., \& Senesi, N. (2006). Fate of anthropogenic organic pollutants in soils with emphasis on adsorption/desorption processes of endocrine disruptor compounds. Pure and Applied Chemistry, 78, 947-961. https://doi.org/10.1351 /pac200678050947.

Loffredo, E., \& Taskin, E. (2017). Adsorptive removal of ascertained and suspected endocrine disruptors from aqueous solution using plant-derived materials. Environmental Science and Pollution Research, 24, 19159-19166. https://doi.org/10.1007/s11356-017-9595-z.

Loffredo, E., Castellana, G., \& Taskin, E. (2016). A two-step approach to eliminate pesticides and estrogens from a wastewater and reduce its phytotoxicity: Adsorption onto plantderived materials and fungal degradation. Water, Air, \& Soil Pollution, 227(6), 188. https://doi.org/10.1007/s11270-0162883-2.

Loffredo, E., Gattullo, C. E., Traversa, A., \& Senesi, N. (2010). Potential of various herbaceous species to remove the endocrine disruptor bisphenol A from aqueous media. Chemosphere, 80(11), 1274-1280. https://doi.org/10.1016 j.chemosphere.2010.06.054.

Loffredo, E., Parlavecchia, M., Perri, G., \& Gattullo, R. (2019). Comparative assessment of metribuzin sorption efficiency of biochar, hydrochar and vermicompost. Journal of Environmental Science and Health, Part B, 54(8), 728735. https://doi.org/10.1080/03601234.2019.1632643.

Loffredo, E., Picca, G., \& Parlavecchia, M. (2020). Single and combined use of Cannabis sativa L. and carbon-rich materials for the removal of pesticides and endocrine disrupting chemicals from water and soil. Environmental Science and Pollution Research (in press). https://doi.org/10.1007 /s11356-020-10690-7.

Lu, C., Chang, C.-H., Palmer, C., Zhao, M., \& Zhang, Q. (2018). Neonicotinoid residues in fruits and vegetables: An integrated dietary exposure assessment approach. Environmental Science \& Technology, 52, 175-3184. https://doi. org/10.1021/acs.est.7b05596.

Marín-Benito, J. M., Sánchez-Martín, M. J., Ordax, J. M., Draoui, K., Azejjel, H., \& Rodríguez Cruz, M. S. (2018). Organic 
sorbents as barriers to decrease the mobility of herbicides in soils. Modelling of the leaching process. Geoderma, 313, 205-216. https://doi.org/10.1016/j.geoderma.2017.10.033.

Mehdizadeh, M., Izadi-Darbandi, E., Yazdi, M. T. N. P., Rastgoo, M., Malaekek-Nikouei, B., \& Nassirli, H. (2019). Impacts of different organic amendments on soil degradation and phytotoxicity of metribuzin. International Journal of Recycling of Organic Waste in Agriculture, 8(Suppl 1), S113-S121. https://doi.org/10.1007/s40093-019-0280-8.

Mukherjee, S., Tappe, W., Hofmann, D., Köppchen, S., Disko, U., Weihermüller, L., Burauel, P., \& Vereecken, H. (2014). Effect of biochar and digestate on microbial respiration and pesticide degradation. EGU General Assembly 2014, held 27 April - 2 May, 2014 in Vienna, Austria, id.20.

Mukherjee, S., Weihermüller, L., Tappe, W., Hofmann, D., Köppchen, S., Laabs, V., Vereecken, H., \& Burauel, P. (2016). Sorption-desorption behaviour of bentazone, boscalid and pyrimenthanil in biochar and digestate based soil mixtures for biopurification systems. Science of the Total Environment, 559, 63-73. https://doi.org/10.1016/j. scitotenv.2016.03.145.

Olaniyan, L. W. B., Okoh, O. O., Mkwetshana, N. T., \& Akoh, A. I. (2018). Environmental water pollution, endocrine interference and ecotoxicity of 4-tert-octylphenol: A review. Reviews of Environmental Contamination and Toxycology, 248, 81-109. https://doi.org/10.1007/398_2018 20.

Parlavecchia, M., D’Orazio, V., \& Loffredo, E. (2019). Wood biochars and vermicomposts from digestate modulate the extent of adsorption-desorption of the fungicide metalaxyl$\mathrm{m}$ in a silty soil. Environmental Science and Pollution Research, 26(35), 35924-35934. https://doi.org/10.1007 /s11356-019-06729-z.

Patama, M., Belz, R. G., \& Sinkkonen, A. (2019). Realistic lowdoses of two emerging contaminants change size distribution of an annual flowering plant population. Ecotoxicology, 28, 732-743. https://doi.org/10.1007/s10646-019-02069-3.

Pavlis, M., Cummins, E., \& McDonnel, K. (2010). Groundwater vulnerability assessment of plant protection products: A review. Human and Ecological Risk Assessment: An International Journal, 16(3), 621-650. https://doi. org/10.1080/10807031003788881.

PubChem (2020) National Center for Biotechnology Information. PubChem open chemistry database at the National Institutes of Health (NIH), U.S. National Library of Medicine. https://pubchem.ncbi.nlm.nih.gov. Accessed 13 August 2020.

Regueiro, J., López-Fernández, O., Rial-Otero, R., CanchoGrande, B., \& Simal-Gándara, J. (2015). A review on the fermentation of foods and the residues of pesticidesbiotransformation of pesticides and effects on fermentation and food quality. Critical Review in Food Science and Nutrition, 55, 839-863. https://doi.org/10.1080 /10408398.2012.677872

Ruela, V. M., Bortolotti da Silva, A., Veiga, A. D., Corrêa de Souza, T., Marques, D. M., de Melo Costa, C. E., \& Teruel Rezende, T. (2019). Growth and physiological response of coffee seedlings treated with fungicides. Coffee Science, 14(2), 138-146. https://doi.org/10.25186/cs.v14i2.1549.

Sharma, A., Kumar, V., Kohli, S. K., Kaur, R., Kaur, T., Arora, S., Thukral, A. K., \& Bhardwaj, R. (2020). Pesticide metabolism in plants, insects, soil microbes and fishes - An overview, in pesticides in crop production: Physiological and biochemical action. Wiley Online Library, John Wiley \& Sons Ltd. https://doi.org/10.1002/9781119432241.ch3.

Shi, Y., Sun, Y., Xu, H., \& Wu, J. (2019). Importance of organic matter to the retention and transport of bisphenol A and bisphenol S in saturated soils. Water, Air, \& Soil Pollution, 230, 43. https://doi.org/10.1007/s11270-019-4096-y.

Silva, V., Mol, H. G. J., Zomer, P., Tienstra, M., Ritsema, C. J., \& Geissena, V. (2019). Pesticide residues in European agricultural soils - A hidden reality unfolded. Science of the Total Environment, 653, 1532-1545. https://doi.org/10.1016/j. scitotenv.2018.10.441.

Sondhia, S. (2005). Phytotoxicity and persistence of metribuzin residues in black soil. Toxicological \& Environmental Chemistry, 87(3), 389-397. https://doi.org/10.1080 /02772240500165505.

Stevens, M. M., Reinke, R. F., Coombes, N. E., Helliwell, S., \& Mo, J. (2007). Influence of imidacloprid seed treatments on rice germination and early seedling growth. Pest Management Science, 64(3), 215-2022. https://doi. org/10.1002/ps.1499.

Sur, R., \& Stork, A. (2003). Uptake, translocation and metabolism of imidacloprid in plants. Bulletin of Insectology, 56, 35-40.

Taskin, E., de Castro Bueno, C., Allegretta, I., Terzano, R., Rosa, A. H., \& Loffredo, E. (2019). Multianalytical characterization of biochar and hydrochar produced from waste biomasses for environmental and agricultural applications. Chemosphere, 233, 422-430. https://doi.org/10.1016/j. chemosphere.2019.05.204.

USEPA Office of Water Report. (2003). Candidate contaminant list regulatory determination support document for m e t r i b u z i n. h t t p s : / / w w w . e p a . gov/sites/production/files/2014-09/documents/support_cc1_ metribuzin_ccl_regdet.pdf. Accessed 13 August 2020.

Xu, N., Zhang, B., Tan, G., Lia, J., \& Wang, H. (2015). Influence of biochar on sorption, leaching and dissipation of bisphenol A and $17 \alpha$-ethynylestradiol in soil. Environmental Science: Processes \& Impacts, 17, 1722-1730. https://doi. org/10.1039/C5EM00190K.

Ying, G.-G., Kookana, R. S., \& Dillon, P. (2003). Sorption and degradation of selected five endocrine disrupting chemicals in aquifer material. Water Research, 37, 3785-3379. https://doi.org/10.1016/S0043-1354(03)00261-6.

Yu, J., Zhu, Z., Zhang, H., Guanglan, D., Qiu, Y., Yin, D., \& Wang, S. (2020). Hydrochars from pinewood for adsorption and nonradical catalysis of bisphenols. Journal of Hazardous Materials, 385, 121548. https://doi.org/10.1016/j. jhazmat.2019.121548.

Zhang, H., \& Wang, J. J. (2014). Loss on ignition method. In F. J. Sikora \& K. P. Moore (Eds.), Soil test methods from the Southeastern United States. Southern extension and research activity information exchange group 6 (pp. 155-157). Athens: University of Georgia http://aesl.ces.uga.edu/sera6 /PUB/MethodsManualFinalSERA6.asp.

Publisher's Note Springer Nature remains neutral with regard to jurisdictional claims in published maps and institutional affiliations. 